\title{
Pelatihan Pemasaran dan Pembukuan Keuangan Dalam Mendapatkan Pembiayaan Bank Syariah Bagi Pedagang Pasar Cileungsi
}

\author{
Novingky Ferdinand, Nurul Iman Maulana, Thoriq Aziz \\ 1,2STEBIS Bina Mandiri Cileungsi, Bogor \\ email: novingky@binamandiri.ac.id
}

\begin{abstract}
Abstrak: Isu pengusaha UMKM tidak Bankable sering jadi isu yang sangat menarik karena kendala UMKM yang masih sederhana dalam melakukan pemasaran dan pembukuan keuangan usaha. Seiring dibukanya akses perbankan seluas luasnya dan dukungan UMKM naik kelas dari pemerintah membuat UMKM harus merespon hal tersebut dengan baik. Tujuan dari pelaksanaaan kegiatan pengabdian kepada komunitas pedagang Pasar Cileungsi adalah Mengembangkan dan meningkatkan kemampuan komunitas pedagang Pasar Cileungsi dalam hal pemasaran dan pembukuan keuangan. Juga, Masalah yang kini jadi fokus pelatihan ini adalah untuk meningkatkan kemampuan UMKM dalam melakukan pemasaran dan pembukuan keuangan yang baik sehingga UMKM menjadi Bankable. Metode yang dilakukan adalah dengan melakukan Pelatihan pemasaran dan pembukuan keuangan sebagai syarat untuk mendapatkan pembiayaan di Bank Syariah. Dari hasil pelatihan para pedagang antusias dan akan komitmen untuk menindaklanjuti pelatihan ini untuk segera membuat pemasaran dan pembukuan keuangan yang baik untuk mengajukan pembiayaan kepada Bank Syariah untuk mengembangkan usahanya.
\end{abstract}

Kata Kunci: Bankable, Bank syariah , UMKM

Abstract: The issue of non-bankable MSME entrepreneurs is often a very interesting issue because of the simple constraints of MSMEs in marketing and accounting for business finances. Along with the opening of banking access as widely as possible and the support of MSMEs to upgrade from the government, MSMEs must respond well to this problem. The purpose of implementing community service activities for the Cileungsi Market traders is to develop and improve the capabilities of the Cileungsi Market merchant community in terms of marketing and financial accounting. Also, the problem that is now the focus of this training is to improve the ability of MSMEs to carry out marketing and good financial accounting so that MSMEs become Bankable. The method used is to conduct marketing training and financial bookkeeping as a condition for obtaining financing at Islamic banks. From the results of the training, the traders were enthusiastic and committed to following up on this training to immediately make good marketing and financial accounting to apply for financing to Islamic Banks to develop their businesses.

Keywords: Bankable, Islamic bank, SME 


\section{Pendahuluan}

Performa yang dialami oleh sebagian besar usaha zona mikro, kecil, serta menengah (UMKM) di Indonesia yang sangat menonjol yaitu rendahnya produktivitas, rendahnya nilai tambah, serta rendahnya mutu produk. Dari sekian jumlah faktor pencetusnya beberapa diantaranya adalah kurangnya tingkat penguasaan teknologi dan kemampuan wirausaha dan pengetahuan pemasaran dan keuangan di kalangan UMKM. Pengembangan UMKM yang sudah dilakukan selama ini tidak memberikan hasil yang cukup baik terhadap produktivitas UMKM, perkembangan ekonomi secara cepat dinegara lain mengakibatkan tingkat daya saing kita tertinggal jauh dibandingkan dengan negaranegara tetangga kita.

Pemerintah maupun perbankan pun telah memberikan dukungan kepada wirausahawan dengan membuka akses keuangan. Dengan dibukanya akses tersebut seharusnya dapat memberi peluang bagi para wirausaha dalam mengembangkan potensi usaha mereka. Pasar Cileungsi Kabupaten Bogor, Jawa Barat adalah daerah yang menjadi lokasi pelaksanaan kegiatan pemberdayaan masyarakat dalam bentuk pelatihan. Masalah yang ada para pedagang pasar Cileungsi adalah tingkat kelayakan mereka untuk bisa memenuhi persyaratan melakukan pembiayaan di Perbankan dalam hal ini Perbankan Syariah dalam hal pemasaran dan pembukuan keuangan usaha yang menjadi syarat utama dalam mengajukan pembiayaan.

Para pedagang kebanyakan tidak Bankable karena biasanya administrasi dari para pedagang tersebut yang kurang baik dan pemasaran dan pembukuan keuangan yang masih sangat sederhana. pemasaran dan pembukuan dalam dunia usaha Mikro kecil menengah membutuhkan bagian kecil dari praktek akuntansi yang penerimaan/pendapatan pengeluaran baik secara tunai maupun kredit (Ikatan Akuntan Indonesia, 2016). Pembukuan pada dasarnya adalah perekaman atau pencatatan semua informasi mengenai transaksi dan kegiatan keuangan dari pebisnis tentang proses akuntansi mereka. Hasil dari proses akuntansi berupa pelaporan keuangan atau pelaporan akuntansi sebagai bentuk informasi keuangan kepada pihak pihak yang membutuhkan (Haryono, 2011)

Menurut (Hasyim, 2014) Sebesar 77,5\% UMKM tidak memiliki laporan keuangan dan sisanya, sebesar $22,5 \%$, memiliki laporan keuangan. Dari sisi jenis laporan keuangan yang dimiliki UMKM, sebesar $23,2 \%$ menyusun neraca, sebesar $34,3 \%$ menyusun laba rugi, menyusun arus kas sebesar $34,4 \%$,dan persediaan barang sebesar $30,9 \%$. Sebesar $53 \%$ hanya memiliki catatan mengenai uang masuk dan keluar.

Untuk mengatasi hal tersebut di atas salah satunya adalah melalui pelatihan yang merupakan salah satu terobosan yang perlu dilakukan secara berkesinambungan yang bisa memberi mereka bekal dalam menghadapi kompetisi di masa yang akan datang, selain itu memberi mereka bekal pengetahuan agar bisa mengetahui hal apa yang perlu dipersiapkan apabila ingin melakukan pembiayaan di Perbankan khususnya Perbankan Syariah.

Dengan kegiatan ini diharapkan UMKM dapat memperbaiki kekurangan yang dibutuhkan untuk bisa disetujui pengajuan pembiayaanya kepada Perbankan khusunya Perbankan Syariah. Berdasarkan kondisi dan potensi yang ada, penulis ingin melaksanakan kegiatan pengabdian masyarakat di Pasar Cileungsi, Kabupaten Bogor, 
Jawa Barat dengan judul "Pelatihan Pengajuan Pembiayaan Di Bank Syariah Bagi Komunitas Pedagang Pasar Cileungsi di Pasar Cileungsi".

Dari hasil survei terdapat satu permasalahan utama yang dapat diidentifikasikan sebagai fokus di dalam pelaksanaan kegiatan PKM oleh tim pelatihan. Masalah tersebut adalah bagaimana cara meningkatkan kemampuan pembukuan keuangan para pedagang di Pasar Cileungsi sehingga layak mendapatkan fasilitas pembiayaan dari Bank Syariah. Dari permasalahan yang ada tersebut, maka tujuan dari pelaksanaaan kegiatan pengabdian kepada komunitas pedagang Pasar Cileungsi adalah Mengembangkan dan meningkatkan kemampuan komunitas pedagang Pasar Cileungsi dalam hal pemasaran dan pembukuan keuangan.

\section{Metode}

Metode yang digunakan dalam pelaksanaan kegiatan pengabdian kepada masyarakat adalah pelatihan dengan cara :

1. Melakukan pengamatan serta persiapan untuk mendapatkan gambaran umum terkait pedagaang UMKM di Pasar Cileungsi.

2. Memberikan pelatihan kepada Pelaku UMKM tentang pembukuan keuangan secara sederhana yang bisa dianggap layak oleh perbankan khususnya Perbankan Syariah.

3. Evaluasi atas pelatihan dengan melihat hasil dari pelatihan sejauh mana pemahaman dari peserta terhadap pembuatan pembukuan keuangan.

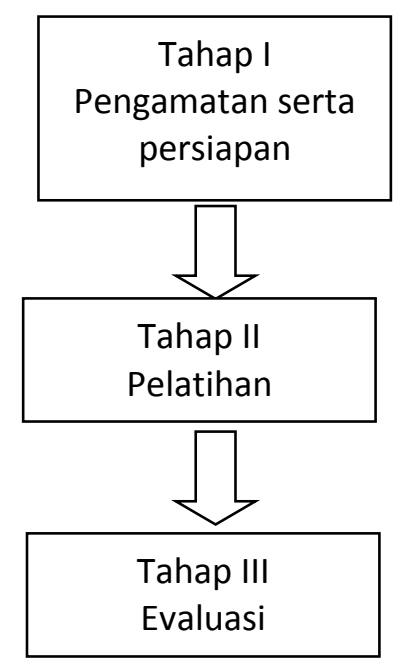

Gambar 1 Tahapan Pelaksanaan Kegiatan

Pelaksanaan kegiatan PKM dilakukan dengan tahapan sebagai berikut: 1.Pada tahap awal melakukan perizinan keapda pihak terkait untuk melaksanakan kegiatan pengabdian masyarakat dengan menandatangani perizinan program pelatihan. 2. Pada tahap pelaksanaan, responden atau peserta berpartisipasi dalam menyediakan sarana dan tempat pelaksanaan 3. Tim Pelatihan melaksanakan pelatihan, dan pendampingan, menyiapkan materi dan bahan/alat untuk menunjang kegiatan yang akan dilakukan. Kegiatan penyuluh dengan tema Pelatihan Pengajuan Pembiayaan Di Bank Syariah Bagi 
Komunitas Pedagang Pasar Cileungsi telah dilaksanakan pada tanggal 14 Juni 2020 . Jumlah Peserta yang hadir pada pelaksanaan PKM ini sebanyak 20 orang

\section{Hasil dan Pembahasan}

Pelaksanaan program kegiatan pada masyarakat ini dilakukan mulai pada bulan Maret 2021 hingga bulan Juni 2021 (4 bulan). Kegiatan ini dimulai dengan mendata secara demografi keberadaan komunitas Pedagang meliputi pendidikan dan pengalaman usaha. Didapat hasil nya rata-rata Pendidikan hanya SMA ke bawah dan pengalaman sudah di atas 5 tahun.

Sebelum tim melakukan kegiatan, sosialisasi dilakukan wawancara dengan masyarakat setempat mengenai rencana pelaksanaan. Permintaan dari komunitas pedagang untuk memperdalam pengetahuan mereka terkait pembukuan sederhana dari sejak wawancara sudah mulai terasa. Di akhir pelatihan, tim penyuluh memberikan kesempatan kepada peserta untuk mengadakan tanya jawab dan juga melakukan pendampingan sebagai alat evaluasi sejauh apa pemahaman dan antusiasme dari peserta terhadap kegiatan pelatihan ini agar kegiatan ini dapat dijadikan sebagai salah satu modal untuk bisa meningkatkan kemampuan komunitas pedagang untuk meningkatkan kemampuan dalam pembukuan keuangan. Dari hasil pelatihan para pedagang UMK mendapatkan insight yang bagus terkait cara melakukan pembukuan keuangan yang baik dan mempraktikkan hasil pelatihan tersebut untuk kemudian digunakan untuk mengajukan pembiayaan ke Bank Syariah.

Selain itu, (Hasbi et al., 2021) para pedagang pasar cileungsi mendapatkan tiga strategi pemasaran produk yaitu: Pertama, Strategi promosi dimana promosi merupakan salah satu strategi yang penting digunakan dalam pemasaran. Saat ini hampir tidak mungkin kita jumpai pedagang yang tidak menggunakan strategi ini baik perusahaan kecil maupun perusahaan besar, begitu juga yang dilakukan oleh pedagang pasar cileungsi. Kedua, Strategi Pelayanan 3 S (Senyum, Salam, Sapa).Senyum, dalam menghadapi konsumen semua karyawan harus menebar senyum seramah mungkin yang membuat konsumen sangat merasa dihargai dan dihormati. Salam, dalam islam sendiri salam sangat dianjurkan ketika kita bertemu dengan setiap orang sebagai tanda bahwa kita mendo'akannya agar selalu sejahtera dengan diberi keselamatan oleh zat yang maha pemberi keselamatan. Sapa, naluri setiap orang termasuk naluri konsumen adalah ingin disapa sebagai ungkapan bahwa mereka diperdulikan oleh orang yang menyapa sehingga ketika konsumen berkunjung ke lapak kita kemudian pedagang tersebut menyapa maka diharapkan konsumen membeli produk kita. Ketiga, Strategi Kreasi Usaha. Strategi ini dipakai oleh pedagang agar konsumen tidak bosan dengan usaha yang kita miliki, karena setiap pedagang menginginkan usahanya berjalan dengan lancar dan memiliki konsumen yang banyak. Sehingga tidak boleh tidak bagi pedagang untuk membuat kreasi usaha agar konsumen yang berlangganan tidak berpindah ke pedagang lain dengan alasan pedagang tersebut tidak memiliki kreasi yang baru dalam usahanya. 


\section{Kesimpulan}

Kegiatan Pengabdian kepada Masyarakat dilaksanakan di Pasar Cileungsi Kabupaten Bogor, dapat disimpulkan sebagi berikut : 1. Dari hasil pelaksanaan, peserta telah menunjukkan pemahaman mereka mengenai pembukuan keuangan secara sederhana yang ditunjukkan dengan pembuatan laporan keuangan yang memenuhi minimum persyaratan untuk melakukan pembiayaan di Bank Syariah seperti cashflow dan laporan laba rugi sederhana pada saat pelatihan 2. Hasil dari pendampingan untuk menunjukkan para peserta telah berhasil mempraktikkan secara mandiri proses pembukuan keuangan secara sederhana yang telah diajarkan yang akan dipergunakan sebagai persyaratan untuk melakukan pembiayaan di Bank Syariah.

\section{Referensi}

Haryono, Y. . (2011). Dasar-dasarAkuntansi (1st ed.). STIE YKPN Yogyakarta.

Hasbi, M. Z. N., Al Farisi, M. S., Cahyani, Y. T., \& Kusbiantoro, S. (2021). Strategi Pemasaran Usaha Pp. Riyadlul Jannah Pacet Mojokerto Perspektif Ilmu Ekonomi Syariah. Jurnal Riset Entrepreneurship, 4(2), 19. https://doi.org/10.30587/jre.v4i2.2544

Hasyim, D. (2014). Kualitas Manajemen Keuangan Usaha Mikro Kecil Menengah (Umkm) (Studi Kasus Pada Distribution Store (Distro) Di Kota Medan). Jupiis: Jurnal Pendidikan IImu-I/mu Sosial, 5(2), 105-114. https://doi.org/10.24114/jupiis.v5i2.1119

Ikatan Akuntan Indonesia. (2016). Standar Akuntansi Keuangan Entitas Mikro Kecil menengah. 